\title{
Non-timber forest products certification in India: opportunities and challenges
}

\author{
Manmohan Yadav $\cdot$ D. Dugaya
}

Received: 24 April 2012/Accepted: 22 September 2012/Published online: 5 October 2012

(C) The Author(s) 2012. This article is published with open access at Springerlink.com

\begin{abstract}
Forest certification has emerged as a marketing tool for linking the good forest management practices with the environmentally conscious consumers. Its genesis can be attributed to the society's concern for the social and environmental significance of forests. Forest management certification when coupled with the chain-of-custody certification; then, the supply chain stages for such forest products can carry an ecolabel. Non-timber forest products (NTFPs) are of socio-economic and cultural importance for the forest dwelling communities, particularly for the tropical countries like India. India is home to an amazing diversity of plants, with over 46,000 plant species recorded to occur there. NTFP's availability, utilization, commercialization, exploitation, management practices, policies and tenure systems in different parts of India have high diversity and variability. There is concern, however, that collection methods for most of NTFP species are destructive and wild populations are declining as a result. Thus, the harvest of NTFPs is coming under increasing scrutiny from certification programmes, as it plays a key role in the sustainable management of forest resources and community benefit worldwide. Thus, the present research paper highlights the issues relevant to certification of NTFPs in India, based on more than a decadal experience in dealing with this subject at Indian Institute of Forest Management, Bhopal.
\end{abstract}

Keywords Forest certification - Ecolabel · Non-timber forest products · Sustainable NTFP management

The paper is a revised version of the presentation made by the lead author at International Conference on Non-Wood Forest Produce for sustained livelihood in December 2011 at Bhopal, India.

M. Yadav $(\varangle) \cdot$ D. Dugaya

Centre for Sustainable Forest Management and Forest Certification, Indian Institute

of Forest Management, Bhopal 462003, India

e-mail: manmohan@iifm.ac.in

D. Dugaya

e-mail: dugayad@iifm.ac.in 


\section{Introduction}

The genesis of concept of forest certification can be attributed to the society's concern for the social and environmental significance of forests. Public concern for the environment has grown remarkably during the last few decades, both in developed and developing countries, and as a result, environmental issues are beginning to take more of a center stage in global economic and trade policies (Perera and Vlosky 2006). Forest certification has emerged as a marketing tool (Mallet and Karmann 2000) for linking the sustainable forest management practices (Rametsteiner 2000; Rametsteiner and Simula 2003) with the environmentally conscious consumers. Non-timber forest products (NTFPs) are of socio-economic and cultural importance for the forest dwelling communities, particularly for the tropical countries like India. The sustainable management of NTFPs possesses real challenges for forest certification. Forest certification refers to two separate processes viz. forest management unit certification (FMU) and chain-of-custody certification (CoC). Forest management certification is a process which verifies that area of forest/plantations from where the wood, fiber and other non-timber forest products are extracted is being managed to a pre-defined standard. $\mathrm{CoC}$ certification is a process of tracking forest products from the certified forest to the point of sale to ensure that the product has originated from a certified forest. Although the basic idea of forest certification is readily understandable, forest certification is not yet a customary practice or a long-standing tradition. Rather, it is an emerging practice. This means that its basic elements must be worked out and converted into standard practices and procedures before forest certification can achieve wide social recognition, particularly in the context of tropical countries like India (Yadav et al. 2011 conference proceedings under publication).

The certification programs have existed in other economic sectors, such as appliance manufacturing, quality control and health care services. The rise of certification programmes in the forestry sector is striking because non-governmental actors are taking up functions traditionally claimed by the agencies and ministries of nation states and the setting and implementation of forestry standards intended to protect broad public interests in proper forest management. But, despite the traditional state predominance in the forestry sector in most countries, forest certification programmes did not have to invent themselves out of thin air. Rather, they were able to draw upon models and techniques that had been developed and standardized by programmes performing similar functions in other sectors. Thus, forest certification is inherently linked to developments in other sectors (Source: Yadav 2012 book under finalization for publication).

NTFP's availability, exploitation, management practices, utilization, commercialization, policies and tenure systems in different parts of India have high diversity and variability, which imposes even greater challenge for development of any generic standards for certification, even though many of the principle, criteria, indicators and verifiers are universally applicable for NTFP certification. The harvest of NTFP is coming under increasing scrutiny from certification programmers, as it plays a key role in the sustainable forest management and community benefit worldwide (Source: Yadav et al. 2011 conference proceedings under publication). Thus, the present research paper highlights the issues relevant to certification of non-timber forest products (NTFP) in India, based on a more than the decadal experience in dealing with this subject at Indian Institute of Forest Management, Bhopal.

\section{Review of existing Forest Certification Schemes}

As on date, there are a handful of international forest certification schemes and many regional and national certification schemes setting up standards for measuring better 
practices toward sustainable management of forests. There is a growing competition among these certification programs to become the global leader which have global operations and coverage. These are Forest Stewardship Council (FSC) and the Program for Endorsement of Forest Certification Schemes (PEFC). The remaining certification schemes are working at national level and thus only catering to the needs of the country specific clients. Many of these certification schemes are mutually recognized by the PEFC.

American Tree Farm System (ATFS) has undergone many changes since its beginnings in 1941 and is now recognized as a credible forest certification system started in 2002 through the Independently Managed Group (IMG). ATFS certifies landowners to the American Forest Foundation's Standards of Sustainability for Forest Certification. It is to ensure market acceptance by undergoing third-party certification audits by independent, ANSI-ASQ National Accreditation Board (ANAB) accredited certification bodies. It has been endorsed by the PEFC in 2008. ATFS focuses on certifying the forestry practices of non-industrial private landowners in the US who own between 10 and 20,000 contiguous acres of forestland not associated with a forest products manufacturing facility (Source: ATFS web site).

The Canadian Standards Association (CSA) is a non-profit voluntary association established in 1919. In 1994, the CSA was asked by federal and provincial governments and a coalition of forestry associations to establish a multi-stakeholder technical committee to develop a SFM standard for Canada. Certified operations are monitored annually to review progress toward achieving SFM targets. The CSA has been mutually recognized by the PEFC since 2005 (Source: CSA web site).

The Forest Stewardship Council (FSC) is an international non-profit organization founded in 1993 by representatives from environmental groups, the timber industry, the forestry professionals, indigenous peoples' organizations, community forestry groups and forest product certification organizations from 25 countries. The FSC has developed a set of global principles and criteria for forest management. There are 10 principles and 57 criteria that address legal aspects, indigenous rights, labor rights, multiple benefits and environmental impacts surrounding forest management. FSC encourages national working groups to adapt these principles and criteria to local ecological, economic and social conditions to create regional or national standards.

The American Forest and Paper Association (AF\&PA) developed the Sustainable Forestry Initiative (SFI) program to document the commitment of member companies in US to sustainable forestry. In 2000, the Sustainable Forestry Board (SFB) was established to oversee the SFI standards development and certification processes. The SFI standard contains 13 objectives covering sustainable forest management, procurement of wood and fiber, public reporting, continuous improvement and mitigating illegal logging. The SFI has been mutually recognized by the PEFC since 2005 .

The Program for Endorsement of Forest Certification Schemes (PEFC) is a membership-based global umbrella organization that provides a mutual recognition framework for national forest certification systems developed in a multi-stakeholder process. The organization was founded in 1999 for the purpose of promoting national forest certification systems, particularly in Europe. It has expanded to recognize systems throughout the world since 2005 and now recognizes national certification systems with standards based on intergovernmental processes for sustainable forest management.

The Malaysian Timber Certification Council (MTCC) was established in 1999 as an independent organization to develop a voluntary national timber certification system in order to provide independent assessment of forest management practices as well as to meet the demand for certified timber products. The MTCS is the first certification scheme in 
Asia, and the second in the South after the Gabonese Forest certification Scheme that has been endorsed by the PEFC (2009) (Source: MTCC web site).

The China Forest Certification Council (CFCC) was set up to develop standards for forest certification and an appropriate forest certification scheme in 2002. The China Forest Certification Standards issued by SFA comprises of 9 principles, 45 criteria and 112 indicators. The CFCC has joined the PEFC in September 2011.

\section{Status of forest certification}

\subsection{Global status}

At the global level, there are two competing certification schemes with different operating modalities. The Forest Stewardship Council (FSC) provides all the necessary elements of certification through centralized decision making on standards and accreditation. The Program for the Endorsement of Forest Certification (PEFC), on the other hand, operates as a system for mutual recognition between national certification systems. Almost two-thirds of the world's certified forests carry a PEFC certificate, while the FSC's share is $28 \%$; the remaining forests are certified solely under national certification systems. Most of the certified forests in the tropics are FSC-certified.

As of August 10, 2012, FSC has certified 164.4 million ha forest area and has issued 24,057 CoC certificates and 1,144 FM/CoC certificates (Source: FSC web site). As of July 2012, there are 31 national certification schemes recognized by the PEFC, 240 million hectares of forest certified, 714,350 forest owners and 9,167 CoC holders of PEFC (Source: PEFC web site).

\subsection{Status of forest certification in India}

A few forest certification projects have been undertaken in India including two FM certificates issued in 2002 one each in UP and West Bengal for small private plantations using FSC standards. The first certification issued in India was a FSC CoC certification which was issued in January 2001 to a Toys manufacturer in Shaharnpur, UP for Babul (Acacia nilotica) and Shisham (Dalbergia sissoo) wood species. The second certification in India was for both FM \& CoC certification issued by FSC in 2002 on 432 acres for Kadam (Ailanthus grandis) plantations in West Bengal. However, both these certificates were discontinued within 1 year of issuances for unknown reasons.

The third and fourth $\mathrm{CoC}$ certifications were also issued in 2002 for Silver Beech (Nortofagus Menziesii) wood species from France imported by hand tool manufacturers in Jalandhar, Punjab. The hand tools are exported to the European countries. Both these certificates are continuing even today and thus are the oldest $\mathrm{CoC}$ certifications in India.

IIFM has done a pioneer work in undertaking Forest Certification pilots for bamboo resource in northeast region in the country, that is, Tripura, Arunachal Pradesh and Nagaland (Yadav et al. 2003). A group of farmers who cultivate local bamboo species in Katlamara region of Tripura using traditional system of sustainable practices was audited by one of the recognized certification body of FSC and the certification almost reached the final stage in the year 2003; however, because of reasons unknown to the authors, the certification could not lead to successful conclusion. This almost a decade old initiative is being taken up again in 2012 by the farmers themselves with the possible support of state agencies like Tripura Forest Development and Plantation Corporation (TFDPC) Limited (Source: Personal communication by farmers and the MD TFDPC Ltd). 
However, currently there are only 4 FSC Forest Management Certificates issued in India in the States of Karnataka, Orissa, Andhra Pradesh and Tamil Nadu with an area of 39,160.49 ha. There are a few more FM certification assessments underway in different parts of the country (Andhra Pradesh and Madhya Pradesh) using FSC standard. These areas either include farm-forestry with corporate support or are community-initiated plantations.

Of late, there has been a sudden increase in chain-of-custody $(\mathrm{CoC})$ certifications in India, particularly since 2006. As a result by July 2012, there were 328 FSC CoC certifications and eleven PEFC CoC certifications issued to divergent types of businesses in India. Preliminary analysis of these $\mathrm{CoC}$ certifications issued for Indian business organizations indicate that majority of the $\mathrm{CoC}$ certifications are owned by small and medium forest-based enterprises. These enterprises represent the pulp and paper mills, wood craft and hand tool enterprises, printers and publication houses, plywood, paper and board industries, timber traders and exporters. However, none of these relate to NTFP certification.

\section{Forest management in India}

Traditionally, forests have been one of the important natural resource, representing a major land use in India. Forest management began with the reservation of Malabar Teak for the Royal Navy in 1806. The first Indian Forest Act was formulated in 1865 enabling the Britishers to acquire, demarcate and reserve forest areas specifically for use of timber for the railways. This Act was replaced by a new Act in 1878, which enabled the British to exercise absolute control over tracts demarcated as valuable forests. The 1878 Forest Act was modified from time to time until a comprehensive Indian Forest Act was enacted in 1927 (Dwivedi 1993). This Act categorized forests into different classes. Each class implied a different level of state control over forests. The first Indian Forest Policy, in 1894, prioritized agricultural interests over forests. Post-independence, the Indian Constitution provided guidelines for protection of forests and wildlife. In 1952, the first Forest Policy of independent India laid that one-third of the total geographical area should be under forest cover hence ensuring balanced and complementary land use system. The basic objectives of realizing maximum annual revenue and making available maximum forest resources for defense, railways and other national objectives remained the cornerstone of India's forest policy until the forest policy change in 1988. The Forest Conservation Act, 1980 was enacted with the basic objective of transferring the power to utilize forests from the purview of State Governments to the ambit of the Union Government. The 1988 forest policy took a major diversion in forest management objectives from resource utilization to conservation of resources and management of forests with the participation of the local communities. The more recent legislation called "Forest Dwellers Rights Act 2006 \{Scheduled Tribes and Other Traditional Forest Dwellers (Recognition of Forest Rights) Act \}" has enabled the forest dwelling communities to receive ownership of the forestland which they had been using for generations for various purposes. As a result, quite large chunk of government-owned forestland is being transferred to the tribal communities in many parts of the country (Source: http://www.forestrightsact.com).

\section{Criteria and indicators approach for sustainable forest management in India}

The sustainable development has been explained by the World Commission on Environment and Development as: 
Sustainable Development is development that meets the need of the present generation without compromising on the ability of future generations to meet their needs (WCED 1987).

This sustainable development concept focuses on sociological, ecological and economical aspects, for strengthening the welfare of human society. The National Forest Policy, 1988 aims at maintaining environment stability and ecological balance. It emphasizes on conserving the natural heritage, preserving flora and fauna, meeting fuelwood, fodder, non-timber forest products and small timber requirements of the rural and tribal population and increasing forest productivity to meet local and national needs. It highlights the involvement of local people in forest protection under the provision of Joint Forest Management (JFM) resolution of Government of India (MoEF 1988; GoI 2007). Sustainable forest management (SFM), an important element of sustainable development (UNCED 1992; UNCED 2000; WSSD 2002), has become vital to meet the requirements of various forest goods and services in perpetuity and to mitigate environmental consequences vis-à-vis economic development. Sustainable forest management encompasses the set of relevant Criteria and Indicators (C\&I) as measures of sustainability of forest resources in a given regional, national or international context. These C\&I for SFM besides measuring sustainability of forests at the national level also envisage effective monitoring at the Forest Management Unit (FMU) level (Yadav et al. 2007).

Criteria and indicators are tools used to define, assess and monitor progress toward sustainable forest management. Criteria and indicators at the national level may be used to guide countrywide policies, regulations and legislations necessary to achieve national objectives. The ultimate aim of Criteria and Indicators approach is to promote improved forest management practices over time and to further the development of healthier and more productive forests, taking into consideration the social, economic, environmental, cultural and spiritual needs of all the stakeholder groups (Castañeda 2000).

\section{Developing C\&I for SFM in India}

Following the global initiatives, IIFM took the initiative named as "Bhopal-India Process" in 1998 for developing C\&I approach for sustainable forest management in India (IIFM 2000). Since then a national draft set of 8 criteria and 37 indicators for SFM in India have been evolved through multi-stakeholder process and are under consideration of the state forest departments for a final view before a policy decision on the same (GoI 2008; Yadav and Dugaya 2009). A separate set of C\&I for the sustainable management of NTFPs and forest plantations is also under review (Source: IIFM web site).

\subsection{NTFP resource and its management in India}

India is home to an amazing diversity of plants, with over 46,000 plant species recorded to occur there. Many of these species are used for medicinal purposes, with approximately 760 known to be harvested from the wild for use by India's large herbal medicine industry (Jain 2004). There is concern, however, that collection methods for many if not most of these species are destructive and wild populations are declining as a result. NTFP's availability, utilization, commercialization, exploitation, management practices, policies and tenure systems in different parts of India have high diversity and variability, which imposes greater challenge for development of any generic standards for certification, even 
though many of the principle, criteria, indicators and verifiers are universally applicable for certification. The harvest of NTFP is coming under increasing scrutiny from certification programmers, as it plays a key role in the sustainable forest management and community benefit worldwide. Thus, NTFPs present many new challenges and opportunities in certification due to the wide range of management practices and difficulty in monitoring their harvest and processing (Source: Yadav et al. 2011 IIFM research report unpublished).

\subsection{NTFPs certification initiatives}

Forest management certification programs mainly assess ecological aspects of resource management, both at the forest and at the species or product level, including chain-ofcustody certification. Many different programs exist on the international, regional and national level, which focus almost exclusively on timber products and include NTFP only marginally (Walter 2002). As highlighted in the study by Sills et al. (2011), many NTFPs were key global commodities and an important component of international trade, driving the fabled spice trade between Asia and Europe, expanding in the colonial period with products such as shea butter (Vitellaria paradoxa) and gum Arabic (Acacia spp.) from Africa and feeding the industrial revolution with products such as rubber from the Amazon (Heavea brasilenses). The economic importance and often exploitative nature of the international trade in NTFPs are amply documented in case studies of particular products, for example, Weinstein (1983) on rubber in the Amazon, Hanson (1992) on gum Arabic in West Africa, Peluso (1992) on rattan in Indonesia and in the history literature (Wolters 1967; Turner and Loewen 1998; Donkin 2003).

In accordance with a study focusing on the key issues, that is, traceability, tenure rights, empowerment, market potential, costs, harvesting and mainstreaming carried out by FAO based on an literature review and the implementation of case studies covering three different species/products and four exporting/importing countries: (1) devil's claw (Harpagophytum procumbens) in Namibia and Germany; (2) shea butter (Vitellaria paradoxa) in Ghana; and (3) brazil nuts (Bertholletia excelsa) in Bolivia identified key challenges for NWFP certification viz. dispersion of producers and products; definition of sustainable harvesting levels; standard quality and complementarily; risk of user's conflicts; unclear market potentials and economic benefits; insufficient product definition and classification; and limited suitability of different certification schemes (Walter 2006).

Despite these challenges, a number of organizations have endeavored to develop standards and good practices for medicinal and aromatic plants (MAPs) during the past one decade. The Guidelines on Good Agricultural Collection Practices (GACP) for Medicinal Plants published by the World Health Organization (WHO 2003) has provided a model for adaptation at national and regional levels. Other examples include guidelines developed by the Swiss Import Promotion Programme (SIPPO) for collection of wild plants marketed as "organic," covering details of collection, drying and processing of wild collected materials as well as purchase, processing and marketing aspects (Muller and Durbeck 2005). Similarly, the Rainforest Alliance's NTFP marketing and management project, for example, has developed standards for NTFP certification that are now being adopted by the FSC (Source: www.refoestingscotland.org). According to the study conducted by Shanley et al. (2005), there are about forty-six commercial non-timber forest products for which certification standards have been approved and there are ongoing evaluations of some of the original products in other countries and forest types. However, these efforts have not been able to make significant impact on the share of commercial value of certified non-timber forest products in the total NTFP trade. 


\subsection{Initiative by WHO, WWF, IUCN and BfN}

The WWF Germany, TRAFFIC, IUCN Canada and the IUCN medicinal Plant Specialist Group (MPSG), and Medicinal Plant Specialist Group (2007) published a framework of practice standards and performance criteria for the sustainable wild collection of MAPs. In October 2008, the FairWild Foundation was endorsed by the four funding institutions of the ISSC-MAP (BfN, TRAFFIC, WWF, and IUCN) as the official owner of the ISSC-MAP standard and the FairWild standard and is now responsible for their global implementation. Under the auspices of FairWild Foundation, the International Standard for Sustainable Wild Collection (ISSC-MAP) and the FairWild Standard will be jointly implemented to assure buyers that products are produced in a socially and ecologically sound manner. ISSC-MAP Version 1.0 consists of 6 principles and 18 criteria. Each criterion is supported by a set of proposed indicators and forms of control or verification. The ISSC-MAP addresses social and economic factors but focuses on ecological aspects that are often neglected: resource assessments and sustainable yields. Collection practices based on biological characteristics of the species (Collection method and intensity) and the development of a management plan including regular monitoring of collection impacts are some of the requirements of ISSC-MAP requirements.

\subsection{FAO approach for NTFP certification}

Wild crafted and semi-domesticated NTFP can also be considered as organic, and many NTFPs such as pine nuts, mushrooms and herbs are increasingly commercialized as organic food products. "Organic agriculture is a holistic production management system which promotes and enhances agro-ecosystem health, including biodiversity, biological cycles, and soil biological activity..." (FAO/WHO 1999).

\subsection{FSC initiative for NTFP certification standards}

Since 1998, the FSC has permitted certification of NTFP management system on a case to case basis. The first FSC approved NTFP certification was granted by SmartWood to Chicle operation in Mexico, in 1999 (SmartWood 1999). FSC's certification system aims to address the ecological, social and economic factors associated with the long-term responsible harvesting of forest resources. The policy was created based on the research and collaborative efforts of the NTFP Working Group (WG) made up of volunteers who worked between 1997 and 2000, this group helped FSC define its direction on NTFP certification (Brown et al. 2002). The application of FSC standards for NTFPs has been implemented in countries like Brazil, Nepal, Bangladesh, China and others.

Brazil has, since the mid-1990s, experience in forest certification for natural and plantation forests, channeling wood and non-timber forest products (NTFP) through partnerships among the corporate and the community. Prof. May (2004) suggested that the beneficial partnerships among corporate and community enterprises and forest families will add synergy to the growing process of certified forest-based production in Brazil.

The FSC certification initiatives in Nepal have been led by Rainforest Alliance and SmartWood working with community owned and managed forests (Federation of Community Forestry Users Nepal-FECOFUN). Twenty-one community forest users groups (CFUGs) of Bajhang and Dolakha districts were part of 14,086 hectares of forests under certification process (Acharya 2007). 


\subsection{Indian initiatives for developing NTFP certification standards}

Development of standards, which provide a quantitative or qualitative yardstick or reference benchmark, is commonplace across industries and are used to set parameters for starting materials, production processes, finished products and services (Ervin and Elliott 1996; ISO 2002). Standards can be either mandatory (e.g., government regulations) or voluntary. By themselves, standards do not guarantee a particular performance threshold. Rather, the process through which they are developed, the technical rigor of the standards themselves, and the consistency and competency with which they are applied determine their value and impact (Pierce and Laird 2003).

Among the few efforts (studies and pilots) for developing standards for NTFP certification in India include developing sustainable harvesting and management standards for Medicinal \& Aromatic Plants (MAPs) from the wild (Bhattacharyya et al. 2009) supported by the National Medicinal Plants Board (NMPB), pilot studies undertaken by IIFM with support from Ministry of Environment and Forests (MoEF) and other studies undertaken by IIFM at its own. The initial framework developed by IIFM was based on the premise that NTFPs can be categorized on the basis of the parts used in medicine and other formulations. According to this approach, the NTFPs can be categorized in eight categories depending upon the parts used in the trade (IIFM 2007) (Table 1).

Following this framework and the Draft National C\&I for SFM in India for the natural forests, IIFM researchers (authors) have developed a set of draft standards for NTFP certification for some selected NTFPs for the central region of the countries. The broad aspects of this standard have been analyzed, and a comparison has been made with FSC standard and other draft standards evolved for sustainable management of NTFP resources in India (Table 2).

The refined version for NTFP certification standard evolved at IIFM includes four principles viz. Policy, legal and institutional framework for sustainable NTFP; Management plan, strategy and operations for sustainable availability; NTFP value chain and market network; and Socio-cultural and spiritual benefits. The NTFP certification standards consist of 17 criteria and 55 indicators encompassing the broad three pillars of sustainability-ecological, social and economic perspective of wild MAP resources (Table 2).

The basic premise of these standards is to help establish a system of management and monitoring of NTFPs harvesting, trade and external communication so that these resources are continuously available for both local use and external trade. The NTFP species selected for the IIFM pilot study for Central India include Diospyros melanoxylon (Tendu Leaves), Terminalia chebula (Harra fruit), Buchanania lanzan (Achar seeds), Emblica officinalis (Aonla fruit) and Cyperus rotundus (Nagarmotha rhyzomes).

However, these standards need to be further refined in more geographical areas and through wider consultations with other stakeholders as well. Future research should also focus on many more NTFP species so as to develop a broad framework of standards for NTFP certification at regional/national level.

\subsection{Opportunities for NTFP certification}

Contribution of NTFPs in the lives of forest dwelling communities has been highlighted in numerous studies. In India, the non-timber forest products are regarded for their socioeconomic and cultural importance. NTFPs contribute to livelihoods in three ways. Firstly, resources are used to meet current consumption needs, as a regular part of subsistence level livelihoods. Secondly, forests are used as "safety nets", where people draw on available 
Table 1 Types of NTFPs and plant parts used

\begin{tabular}{|c|c|c|c|}
\hline S no. & Plant part & Type of NTFP & Some examples \\
\hline 1 & Underground parts & Root, rhizome, tuber, etc. & $\begin{array}{l}\text { Chlorophytum spp., Cyperus spp., } \\
\text { Vetiveria zizanoides and the like }\end{array}$ \\
\hline 2 & Stem & Bark, gum, resin, etc. & $\begin{array}{l}\text { Terminalia arjuna, Sterculia urens, } \\
\text { Anogeissus latifolia, Shorea } \\
\text { robusta, Pinus roxburghi, etc. }\end{array}$ \\
\hline 3 & Leaf & $\begin{array}{l}\text { Biri making, leaf plate making, } \\
\text { etc. }\end{array}$ & $\begin{array}{l}\text { D. melanoxylon, Bauhinia vahli, } \\
\text { Shorea robusta, etc. }\end{array}$ \\
\hline 4 & Flower & $\begin{array}{l}\text { For food, medicine, dye, } \\
\text { etc. }\end{array}$ & $\begin{array}{l}\text { Madhuca indica, Woodfordia } \\
\text { fruticosa, etc. }\end{array}$ \\
\hline 5 & Fruit & For food and medicine & $\begin{array}{l}\text { E. officinales, T. chebula, } \\
\text { T. bellirica, etc. }\end{array}$ \\
\hline 6 & Seed & Edible and oil & $\begin{array}{l}\text { B. lanzan, Shorea robusta, } \\
\text { Schlishera oleosa, etc. }\end{array}$ \\
\hline 7 & Entire plant & $\begin{array}{l}\text { Mostly the herbs, medicinal } \\
\text { importance }\end{array}$ & $\begin{array}{l}\text { Andrographis paniculata, Boerhavia } \\
\text { diffusa, Phyllanthus niruri, } \\
\text { Centella asiatica, etc. }\end{array}$ \\
\hline 8 & $\begin{array}{l}\text { Animal products } \\
\text { [excluding the } \\
\text { scheduled } \\
\text { species under } \\
\text { wildlife } \\
\text { (protection)] }\end{array}$ & Honey, lac, fishes & Apis spp., Laccifera spp. \\
\hline
\end{tabular}

Source: IIFM (2007)

resources to meet emergency shortfalls and to keep from getting worse off in times of need. Thirdly, forests are used as sources of income generation through the collection and sale of a range of flora and fauna products as raw materials (ICCF 2005).

Yadav and Misra (2010) have reported that the contribution of NTFPs in total annual income of the households in tribal areas of Central Indian states was $31 \%$ (Chhattisgarh), $19.3 \%$ (Madhya Pradesh) and $14.6 \%$ (Vidarbha region in Maharashtra). Research conducted by the Center of Mountain Ecosystem Studies shows that NTFPs are an important source of household supply and cash income for the majority of upland farmers in Southwest China (Stark et al. 2008).

Thus, it is evident that non-timber forest products (NTFPs) can play a key role in sustainable rural development due to their ability to support rural livelihoods while contributing to environmental objectives, including biodiversity conservation. However, the economic importance of the NTFPs often leads to destructive and/or many a times over exploitation of the forest produce. The harvesting techniques as well as the harvesting level for most of the NTFPs producing species have not been standardized.

The process of certification of NTFP can be a vehicle to achieve sustainable management of these resources. Although the certification cannot directly guarantee the sustainable management of NTFPs, the process of achieving certification, which requires thirdparty assessment, may lead to sustainable management of NTFPs. Also, certification may provide a platform to spur social changes and raise awareness for sustainable forestry (NTFP) practices (Pierce et al. 2008).

The socio-economic benefits of NTFPs to the local communities and the growing global concern for responsible management of natural resources provides a unique opportunity for initiation of forest certification programs. 
Table 2 Analysis of frameworks for the certification standards for NTFPs

\begin{tabular}{|c|c|c|c|}
\hline \multirow{2}{*}{$\begin{array}{l}\text { Broad category of } \\
\text { principles (FSC) } \\
\text { (number of criteria and } \\
\text { indicators included) }\end{array}$} & \multicolumn{3}{|c|}{ Principles suggested by scheme/study/pilot projects } \\
\hline & $\begin{array}{l}\text { NMPB } \\
\text { supported study }\end{array}$ & MoEF supported study & IIFM supported study \\
\hline $\begin{array}{l}\text { Principle \#1: } \\
\text { Compliance with Laws } \\
\text { and FSC Principles } \\
(\mathrm{C}-5)^{\mathrm{a}} \\
\text { Principle \#2: Tenure and } \\
\text { use Rights and } \\
\text { Responsibilities (C-3) }\end{array}$ & $\begin{array}{l}\text { 1. Legal and } \\
\text { policy } \\
\text { framework } \\
\text { (C-4) }\end{array}$ & $\begin{array}{l}\text { Principle-1: Legal, } \\
\text { Policy, Institutional \& } \\
\text { Ethical requirements } \\
\text { (C-4 \& I-12) }\end{array}$ & $\begin{array}{l}\text { Principles \# 1: Policy, legal and } \\
\text { institutional framework for } \\
\text { sustainable NTFP (C-3 \& I-12) }\end{array}$ \\
\hline $\begin{array}{l}\text { Principle 9: Maintenance } \\
\text { of High Conservation } \\
\text { Value Forests (C-4) }\end{array}$ & $\begin{array}{l}\text { 2. Wild area } \\
\text { conservation } \\
\text { and } \\
\text { management } \\
\text { (C4) }\end{array}$ & $\begin{array}{l}\text { Principle-2: } \\
\text { Conservation and } \\
\text { Management } \\
\text { Requirements of } \\
\text { NTFPs (C-4 \& I-10) }\end{array}$ & $\begin{array}{l}\text { Principle \# 2: NTFP } \\
\text { management plan, strategy and } \\
\text { operations for Sustainable } \\
\text { Availability (C-7 \& I-24) }\end{array}$ \\
\hline $\begin{array}{l}\text { Principle \#7: } \\
\text { Management Plan } \\
\text { (C-4) } \\
\text { Principle \#8: Monitoring } \\
\text { and Assessment (C-5) }\end{array}$ & $\begin{array}{l}\text { 3. Responsible } \\
\text { collection and } \\
\text { use practices } \\
\text { (C-4) }\end{array}$ & $\begin{array}{l}\text { Principle-3: } \\
\text { Requirements of Good } \\
\text { Collection Practices } \\
\text { (C-5 \& I-17) }\end{array}$ & $\begin{array}{l}\text { Considered in all } 4 \text { principles for } \\
\text { the policy; management plan, } \\
\text { strategy. }\end{array}$ \\
\hline $\begin{array}{l}\text { Principle \# 5: Benefits } \\
\text { from the Forest (C-6) }\end{array}$ & $\begin{array}{l}\text { 4. Economic } \\
\text { development } \\
\text { and benefit } \\
\text { sharing }(\mathrm{C}-4)\end{array}$ & - & $\begin{array}{l}\text { Principle \#3: NTFP Value chain } \\
\text { and market network } \\
\text { (C-5 \& I-13) }\end{array}$ \\
\hline $\begin{array}{l}\text { Principle \#6: } \\
\text { Environmental Impact } \\
(\mathrm{C}-10)\end{array}$ & - & - & - \\
\hline $\begin{array}{l}\text { Principle \#3: Indigenous } \\
\text { Peoples' Rights (C-4) } \\
\text { Principle \#4: } \\
\text { Community relations } \\
\text { and Worker's Rights } \\
\text { (C-5) }\end{array}$ & - & $\begin{array}{l}\text { Principle-4: Social } \\
\text { Equity \& Fair Trade } \\
\text { Requirements } \\
\text { (C-5 \& I-13) }\end{array}$ & $\begin{array}{l}\text { Principle \#4: Socio-cultural and } \\
\text { spiritual benefits (C-2 \& I-5) }\end{array}$ \\
\hline $\begin{array}{l}\text { Principle \# 10: } \\
\quad \text { Plantations (C-8) }\end{array}$ & - & - & - \\
\hline
\end{tabular}

${ }^{a}$ In parentheses are number of criteria (and indicators) within each principle

\subsection{Challenges for NTFP certification}

For many certification programs, NWFP certification is still challenging since the specifics of NWFP certification in comparison with timber and cultivated products are not yet well analyzed and documented. Since certification of NWFP only started recently, experiences in the procedure and the details of NWFP certification are still lacking (Mallet 2000).

The commercialization of NTFPs as a result of increasing interest in natural products has got the attention of conservationist and the policy makers for its potential consequences of depletion of these resources. Such an apprehension is based on the fact that the businesses inherently pursue short-term goal of maximizing profits leading to excessive exploitation and destructive methods of NTFP collection. A forest certification system that has foundation on rigorous standards for sustainable harvest levels, scientific and good collection practices, biodiversity conservation, strong involvement of local community 
through appropriate economic benefit sharing can help to address some of the problems of NTFP management practices and simultaneously create demand for a differentiated product for premium green consumers. However, in absence of clear understanding of the market forces (demand \& supply trend), marketing expertise and social complexity of NTFP operations can make the certification effort fruitless (Pierce et al. 2008). The first FSC label for NTFP - Chicle gum failed in the market place because of a slump in global demand of chewing gum (Shanley et al. 2008). The forest certification labels (FSC \& PEFC) have not yet penetrated deep in the consumers' minds as has happened in case of an appeal of organic certified products. Thus, there is strong need for promoting the responsible NTFP management label through highlighting the key benefits to the general public. The social challenge to NTFP certification is based on the fact that most NTFP collection takes place from the common forestlands and thus absence of secure land tenure for NTFP gatherers (despite usufructs rights for NTFP collection under the Indian Forest Policy 1988) - the fundamental requirement under FSC certification scheme and thus exclusion of NTFP gatherers for NTFP certification system.

Another challenge of NTFP certification is inadequate scientific knowledge about NTFP life cycle, population density, distribution, regeneration, level of sustainable harvesting, etc. Many a times the usable part of the plant as NTFP is regenerating plant propagules. This requires restriction in collection of NTFPs for adequate regeneration of the species in future.

Certification systems have rigidities that can be particularly problematic when applied to NTFPs (Pierce et al. 2008). This requires more in-depth pilot studies to develop a comprehensive NTFP certification system, particularly in the country like India where the collection of NTFPs is the usufructs right of forest dwelling communities with some exceptional cases, that is, collection from the protected areas. Traceability with respect to origin of NTFPs is another big challenge to NTFP certification.

The group certification of NTFP collectors and Small and Low Intensity Managed Forest (SLIMF) of FSC can facilitate a cost efficient certification for small holder but is not enough for NTFP gatherers whose collection is specific to a NTFP and from geographically wide areas because FSC system is area based and not product based or harvest based.

According to Shanley and Stockdale (2008), Timber-a single, well-defined producthas generated a large investment in time and energy to set standards and guidelines and to put in place a credible system of certification and monitoring. However, in case of NTFPs, the variety and variability of parts used and diverse methods of extraction possess the huge challenges for the development of NTFP certification standards. Further, the minimum acceptable standards for NTFP production must consider phenology of plant vis-à-vis the socio-economic and cultural aspects prevailing in the locality. Another challenge to sustainable harvesting of NTFPs is ever increasing demand on account of green consumerism and the decreasing trend of resource availability. Thus, a holistic approach with certification standards can provide an opportunity to organize NTFP production in a professional way to meet the needs of markets as well as the livelihoods of the local community.

The standards for certification of NTFPs must incorporate some aspects such as harvesting practices and harvesting seasons which are specific to a particular type of NTFP as well as their differences in the utilizable plant parts. Wiersum et al. (2008) have highlighted that owing to the huge variety in NTFPs, it is not possible to set a simple set of criteria of ecological sustainability but criteria must be product or category specific.

Accordingly a generic set of standards encompassing specific requirement/condition of NTFP management have been attempted to develop broad framework of forest certification of NTFPs in India (Table 3). These generic standards then could form the basis for a specific NTFP species or products certification standard applicable at the local/regional level. 
Table 3 Draft set of standards for NTFP certification

Criteria Indicators Verifiers

Principles \# 1: Policy, legal and institutional framework for sustainable NTFP management

Criterion 1.1 Use rights/ responsibilities and tenures are well established and are complied
1.1.1 Local/bonafide/primary collectors having clear rights and responsibilities to access, use and manage the NTFP resources

1.1.2 Awareness about rights and responsibilities

\subsubsection{Compliance of orders/Legal} Provisions

1.1.4 Traditional knowledge, practices, cultural and spiritual values are protected

1.1.5 Provision of equitable distribution of economic benefits from NTFP trade

1.2.1 Laws and regulations for NTFP conservation and development including provisions of Biological Diversity are notified

1.2.2 Policy/guidelines for preparation of Management plan/Working Plan/ Micro-plan for management of NTFPs

1.2.3 Specific notification issues for the collection of various categories of NTFPs ${ }^{\mathrm{a}, \mathrm{b}, \mathrm{c}}$

1.2.4 Ensure implementation of the guidelines/salient features of the National Afforestation Program (NAP) in raising the plantations of fruit yielding NTFPs ${ }^{\mathrm{a}}$
Document/notification on traditional conservation practices

Area map and other records (e.g., Nistar Patrika or other local similar documents)

Micro-plan/management plan for NTFP is prepared and available at $\mathrm{DFO} / \mathrm{RO} /$ JFMC

Extension material

Circulars/guidelines for sustainable collection and use are issued and are available at DFO/RO/JFMC

Harvesting calendar is prepared and available at $\mathrm{DFO} / \mathrm{RO} / \mathrm{JFMC}$

JFM resolution made available to JFMC members

Monitoring and Reporting on compliance of NTFP related laws and rules

There are provisions for documentation and using IK

There are provisions for respecting cultural and spiritual values are protected

NTFP collectors must be promoted to organize themselves \& undertake NTFP collection, value addition \& marketing activities to the extent possible

Provision of Support price to the NTFP collectors where the NTFP is sold in raw form

Institutional mechanism and facilities for NTFP collection, storage, processing and marketing

Records of notifications and amendments thereof for NTFP conservation and development are available at $\mathrm{DFO} / \mathrm{RO} /$ JFMC

Biodiversity register

Records of compliance of National/State laws and regulations and Community traditions for conservation of NTFPs

Documents on traditional conservation and development practices of NTFPs

Existence of policy/guidelines for preparation of Management plan/ Working Plan/Micro-plan/with the prescriptions for management of NTFPs

Notification in local vernacular language

Use of quality planting material Involvement of local community in management and planting operations

Improvement in livelihoods of the forestfringe communities 
Table 3 Draft set of standards for NTFP certification

\begin{tabular}{|c|c|c|}
\hline Criteria & Indicators & Verifiers \\
\hline \multirow[t]{5}{*}{$\begin{array}{l}\text { Criterion 1.3 Laws and regulations for } \\
\text { Trade, transit and storage and } \\
\text { processing of NTFPs are in place }\end{array}$} & $\begin{array}{l}\text { 1.3.1 Policy/guidelines for Trade, } \\
\text { transit, storage and processing } \\
\text { of wild/Planted NTFPs }\end{array}$ & $\begin{array}{l}\text { Documents on notification for NTFP trade, } \\
\text { transportation, storage and processing } \\
\text { with FD, Federation/Division/JFMCs }\end{array}$ \\
\hline & & $\begin{array}{l}\text { Requirement of registration of collectors/ } \\
\text { Traders/Processors/end-users }\end{array}$ \\
\hline & & Records of compliance/monitoring \\
\hline & $\begin{array}{l}\text { 1.3.3 Provisions for actions } \\
\text { against violations }\end{array}$ & $\begin{array}{l}\text { Registration of Violation cases against } \\
\text { NTFP management and trade rules }\end{array}$ \\
\hline & & Procedure and type/amount of penal action \\
\hline
\end{tabular}

Principle \# 2: NTFP management plan, strategy and operations for Sustainable Availability

Criterion 2.1 Inventorying, assessment and periodic monitoring of the NTFP resources

Criterion 2.2 NTFP focused forest management plan is in place

Criterion 2.3 Conservation plan for Sensitive/RET/IUCN Red List species and their habitats

Criterion 2.4 Conservation strategy and action plan is in place to maintain the germplasm of NTFPs
2.1.1. Conservation status assessment of the socioeconomically important species

2.1.2 Field assessment of impact of conservation measures

2.1.3 Primary collectors/ Community responsibility for NTFP resource protection

2.1.4 Identification of area rich in NTFPs $^{\text {a,b,c }}$

2.1.5 Marking of plus/elite trees for the collection of quality planting material ${ }^{\mathrm{a}}$

2.2.1 Micro-plan/Working plan/ Management plan focusing on NTFPs.

2.2.2 Use of ITK in preparation of plans

2.2.3 Availability of plan in local language

2.3.1 Conservation measures (i.e., in situ/ex situ) for RET species

2.3.2 Habitat/ecosystem conservation planning

2.4.1 Special conservation programs

2.4.2 Conservation of plant genetic resources

2.4.3 Separate seed/planting stock storage facilities for the best planting material $^{\mathrm{a}, \mathrm{c}}$
Reports on status of the species/habitats Availability, harvestable level

Minutes of the JFMC/GRAM SHABHA meeting

Assessment report of JFMC/GRAM SHABHA/SFDs

JFMC members are aware about rules and regulations for the NTFP resource conservation and development

Evidence of measures for NTFP protection (JFMC minutes, patrolling, social fencing, absence of violation cases, etc.)

Result of periodic monitoring on resource health and productivity

Map showing the NTFP-rich area

Seed Production Area

Approved plan for the period.

Approved plan document with a chapter on ITK

Plan summary and recommendations in local language

List of threatened species of the area

The conservation plan of identified species.

Conservation plan of threatened species

Documents/registers of conservation areas Inspection reports/registers

Register indicating the in situ/ex situ measures

Details of seed source/planting material 
Table 3 Draft set of standards for NTFP certification

\begin{tabular}{|c|c|}
\hline Criteria & Indicators \\
\hline \multirow{3}{*}{$\begin{array}{l}\text { Criterion } 2.5 \text { Maintenance of } \\
\text { biodiversity, health and } \\
\text { vitality }\end{array}$} & $\begin{array}{l}\text { 2.5.1 Biodiversity conservation } \\
\text { function and value }\end{array}$ \\
\hline & 2.5.2 Health and vitality of resources \\
\hline & 2.5.3 Regeneration status \\
\hline \multirow{6}{*}{$\begin{array}{l}\text { Criterion } 2.6 \text { Good field } \\
\text { collection practices are } \\
\text { prescribed and are followed }\end{array}$} & $\begin{array}{l}\text { 2.6.1 Manual on good field collection } \\
\text { practices }\end{array}$ \\
\hline & $\begin{array}{l}\text { 2.6.2 Regulated collection/harvesting } \\
\text { of species/categories of species. }\end{array}$ \\
\hline & $\begin{array}{l}\text { 2.6.3 Preparation of harvesting } \\
\text { calendar. }\end{array}$ \\
\hline & 2.6.4 Tending operations ${ }^{b}$ \\
\hline & 2.6.5 Optimization of resource $u^{\mathrm{a}, \mathrm{c}}$ \\
\hline & $\begin{array}{l}\text { 2.6.6 Compliance to sustainable } \\
\text { collection practices }\end{array}$ \\
\hline \multirow[t]{2}{*}{$\begin{array}{l}\text { Criterion } 2.7 \text { Conservation } \\
\text { and maintenance of soil } \\
\text { and water resources }\end{array}$} & $\begin{array}{l}\text { 2.7.1 Area treated under soil and } \\
\text { water conservation measures in } \\
\text { NTFP-rich areas }\end{array}$ \\
\hline & $\begin{array}{l}\text { 2.7.2 Duration of water flow in the } \\
\text { selected streams }\end{array}$ \\
\hline
\end{tabular}

Principle \#3: NTFP Value chain and market network

Criterion 3.1 Registration of gatherers, traders and other stakeholders are in place
3.1.1 Institutional mechanism for registration of NTFP collectors/ Traders/Processors/end-use industries

3.1.2 Periodic review of registered collectors/traders/processors/endusers

3.2.1 Maintaining records of NTFP Trade, Transit pass and stock data

\section{Verifiers}

Report of NTFP/biodiversity resource assessment report

Management plans; Periodical assessment reports

Regeneration assessment reports in respect of area and species

Manual on Good Field Collection Practices Annual notification on commencement of collection season issued by SFD.

Species-wise tentative target for the extraction of NTFP

List of species under different IUCN categories

Harvesting calendar in local vernacular and is made available to the JFMC/Gram Shabha

Execution of tending operations as per the prescriptions/set norms within the time frame

Guidelines on Good Field Collection Practices

Monitoring and evaluation report

Divisional records/District Records/JFMC/

GRAM SHABHAs records

Divisional records/District Records/JFMC/

GRAM SHABHAs records

Detailed procedure for registration of collectors/ Traders/Processors/end-users with formats

Traders operating in more than one division and outside a given forest division must be registered at the state level federation also

NTFP Processors and user industries must be registered at the state level federation

Registration records with quantity of NTFP

Collected/Traded/processed during the last 3 years

Records of regular review of Registration records including matching the records at state level federation, DFO, range level and JFMC level stakeholders

Register maintained at different level

Web site of Forest Department/NTFP Federation/ Corporation/Division level

Periodic mandatory disclosure reports by all SH on NTFP collection, trade quantity and value, processing and sales quantity and value species-wise and geographical area-wise

For protected species if production from cultivated areas should be certified by $\mathrm{RO} /$ DFO.

Records of transit passes issued by Panchayat/ Range Officer/DFO

Records of TP, species-wise collection and trade data at JFMC/GRAM SHABHA and other field management units (Beat, Range, FMU)

Register of certificates issued by competent authorities with respect to RET species 
Table 3 Draft set of standards for NTFP certification

\begin{tabular}{lc}
\hline Criteria & Indicators \\
\hline & $\begin{array}{c}\text { 3.2.2 Actions against violation of } \\
\text { NTFP management }\end{array}$ \\
$\begin{array}{ll}\text { Criterion 3.3 Processing and value } \\
\text { additions strengthen diversification } \\
\text { of local economy leading to social }\end{array}$ & $\begin{array}{c}3.3 .1 \text { Skill up-gradation facilities } \\
\text { for local value addition of }\end{array}$ \\
equity & NTFPs \\
& \\
& $\begin{array}{l}3.3 .2 \text { Primary processing facility } \\
\end{array}$ \\
& $\begin{array}{l}3.3 .3 \text { Easy accessibility to micro- } \\
\text { finance/micro-credit }\end{array}$ \\
& \\
Criterion 3.4 The gatherers and & 3.4.1 Organized groups/Self-Help \\
processing workers are organized & Groups/Committees/Societies/ \\
into enabling institutions & JFMC/GRAM SHABHAs/ \\
& Federations, etc.
\end{tabular}

Verifiers

Records of cases of violations and action taken thereof

Training module

No. of trainings conducted and personnel trained

Training feedback

No. of SHGs/No. of CCFCs

Type of facilities

No. of micro-finance institutions in the area and no. of beneficiaries and groups and the linkage established

NTFP collector/SHG credit cards

NTFP collectors are organize into SHGs to undertake NTFP collection, value addition and marketing activities to the extent possible

Support price given to the NTFP collectors where the NTFP is sold in raw form

Institutional mechanism and facilities are created for NTFP collection, storage, processing and marketing

3.4.2 The functionality of groups

Proceedings of the meetings, election, audit reports

3.4.3 Price fixation of the raw/ processed material on the basis of demand-supply assessment

Price fixation process and proceeding

Support price of NTFP

Agreement document

3.4.4 Equitable profit distribution Document on benefit sharing mechanism mechanism

Social and financial audit reports

Survey reports

Criterion 3.5 Assured marketing is required for improving the income and employment of local people

3.5.1 Availability of authentic market information

\subsubsection{Developing marketing} Networks

\section{Principle \#4: Socio-cultural and spiritual benefits}

Criterion 4.1 Maintenance/ enhancement of socio-cultural and spiritual benefit
4.1.1 Respect to traditions and rituals relating to NTFP collection practices

\subsubsection{Promotion of cultural} activities related to NTFPs

\subsubsection{Corporate Social} Responsibility as a part of the NTFP processing units/ industries

Criterion 4.2 Safe working conditions are provided to workers
4.2.1 Safety measures for gatherers
Survey/study reports on household collection and consumption.

Newsletter, pamphlets, Web sites, etc., Notice boards, Kiosks at Federation/ Division/JFMC/Panchayat level

Existence of Agencies (Federation, Corporation, Boards)

Market bulletins

Documents on traditional rituals and practices

Consideration to the spiritual values and practices in NTFP management including harvesting and trade

Documentation of cultural/spiritual benefits from the NTFPs

Organization of fair/Haat

Records of CSR activities

No. of trainings received

List of equipments supplied 
Table 3 Draft set of standards for NTFP certification

\begin{tabular}{|c|c|c|}
\hline Criteria & Indicators & Verifiers \\
\hline & $\begin{array}{l}\text { 4.2.2 Insurance cover for the gatherers and processing } \\
\text { workers }\end{array}$ & Insurance cover \\
\hline & 4.2.3 Compliance with relevant laws/regulations & $\begin{array}{l}\text { No. of safety trainings and drills } \\
\text { Report of incidence of accidents }\end{array}$ \\
\hline \multicolumn{3}{|c|}{ Source: Yadav et al. (2011), IIFM study (unpublished) } \\
\hline \multicolumn{3}{|c|}{$\begin{array}{l}\text { a Specific set for flower/fruit/seed category of NTFP with special emphasis on Aonla (E. officinalis), Harra (T. Chebula) } \\
\text { and Achar (B. lanzan) }\end{array}$} \\
\hline
\end{tabular}

The information and periodic data on the identified indicators would form the basis for assessment for certifying the NTFPs. Further, the data for these indicators would be compared against their threshold values. These standards would be used to certify both sustainable collection practices in the forest area from where the NTFPs are being sustainably extracted and chain-of-custody. Certification standards are benchmarks meant to provide a comparison with the existing situation. It provides a tool to the resource manager to ascertain whether the management activity conforms to the standards/benchmarks and, if not, how far or close it is with reference to the benchmark.

\section{Conclusions and suggestions}

Forest certification has emerged as a marketing tool to address the society's concern for the social and environmental significance of forests. Non-timber forest products (NTFPs) are of socio-economic and cultural importance for the forest dwelling communities in countries like India which is home to an amazing diversity of plants. Similarly, NTFP's availability, utilization, commercialization, exploitation, management practices, policies and tenure systems in different parts of India have high diversity and variability. Therefore, a system for certification of NTFPs is much more complex than for timber. Thus, when applying forest certification standards for NTFPs, the habit and phenology of NTFP producing species together with the ecological, economic and socio-cultural aspects must be considered. Accordingly, the IIFM pilot study for development of standards for NTFP certification has categorized NTFP yielding species in three categories, that is, flower/fruit/ seed; leaf; and root/rhizome/tuber and has suggested a draft generic standard for further refinement through studies in more geographical areas along with covering more types of NTFP yielding species. Such studies will help in finalizing these draft standards into a comprehensive generic NTFP certification standard. The learning's from such studies coupled with progressive thinking among certification schemes like FSC Group Certification and SLIMF models can propel the need for NTFP certification for the benefit of NTFP resources, sustainable livelihoods to the local communities traditionally dependent on NTFPs, bio-diversity conservation and a responsible NTFP-based business including international trade.

Open Access This article is distributed under the terms of the Creative Commons Attribution License which permits any use, distribution, and reproduction in any medium, provided the original author(s) and the source are credited. 


\section{References}

Acharya, B. P. (2007). Practice \& implementation of forest certification in Nepal: A case study from some CFUGs in Dolakha district. Thesis submitted to University of Natural Resources \& Applied Life Sciences for partial fulfillment of Master in Forest Science (Mountain Forestry). Retrieved June 28, 2011, from http://www.forestrynepal.org/images/thesis/MSc_BPAcharya.pdf.

BfN. (2007). Medicinal Plant Specialist Group. International Standard for Sustainable Wild Collection of Medicinal and Aromatic Plants (ISSC-MAP). Version 1.0. Bundesamt für Naturschutz (BfN), MPSG/ SSC/IUCN, WWF Germany, and TRAFFIC, Bonn, Gland, Frankfurt, and Cambridge (BfN-Skripten 195). http://www.bfn.de/fileadmin/MDB/documents/service/skript195.pdf.

Bhattacharyya, R., Asokan, A., Bhattacharya, P., Prasad, R., et al. (2009). The potential of certification for conservation and management of wild MAP resources. Biodiversity and Conservation, 18(13), 3441-3451.

Brown, L., Robinson, D., Karmann, M., et al. (2002, October). The FSC and Non-timber forest products certification: A discussion paper. Forest Stewardship Council (FSC). http://www.giz.de/Themen/en/ SID-7E79CE59-CD744FDD/dokumente/en-d59-fsc-and-non-timber-forest-product-certification-discu. pdf.

Castañeda, F. (2000). Criteria and indicators for sustainable forest management: International processes, current status and the way ahead. Unasylva, 203(51), 34-40. ftp://ftp.fao.org/docrep/fao/x8080e/ x8080e06.pdf.

Donkin, R. A. (2003). Between east and west: The Moluccas and the traffic in spices up to the arrival of Europeans. Philadelphia, PA: American Philosophical Society.

Dwivedi, A. P. (1993). A text book of silviculture. Dehradun: International Book Distributors.

Ervin, J., \& Elliott, C. (1996). The development of standards. In V. Viana, J. Ervin, R. Donovan, C. Elliott, \& H. Gholz (Eds.), Certification of forest products, issues and perspectives (pp. 33-41). Washington, DC: Island Press.

GoI. (2007). India's forests. In J. Kishwan, D. Pandey, A. K. Goyal, \& A. K. Gupta (Eds.), Government of India, Ministry of Environment and Forests. New Delhi: GoI. ifs.nic.in/rt/book/Cover\%20Page.pdf.

GoI. (2008). Final draft-annotations for modified/improved C\&I for Sustainable Forest Management (SFM). Government of India, Ministry of Environment and Forests, GoI, New Delhi. www.iifm.ac.in.

Hanson, J. H. (1992). Extractive economies in a historical perspective: Gum Arabic in West Africa. Advances in Economic Botany, 9, 107-114.

ICCF. (2005). Stakeholder organisation in the NTFP sector: Need for a sustainable business model. In Proceeding of National Expert Consultation on NTFP Business Model, 25-26 July 2005. http://pubs.iied.org/pdfs/G02293.pdf.

IIFM. (2000). Bhopal-India Process for Sustainable Management of Natural Forests. SFM Series 01. Indian Institute of Forest Management, Bhopal. www.iifm.ac.in/sfmindia.

IIFM. (2007). Bhopal-India process as the basis for developing standards and integrated approach of forest certification. C\&I India Update (Vol. 6 No. 1, p. 9). Bhopal: Indian Institute of Forest Management. www.iifm.ac.in/sfmindia.

Jain, P. (2004). Certifying certification: Can certification secure a sustainable future for medicinal plants, harvesters and consumers in India? TRAFFIC Online Report Series No. 9. Cambridge, UK: TRAFFIC International. Retrieved January 16, 2012, from www.traffic.org/medicinal.

Mallet, P. (2000). NTFP certification: Challenges and opportunities. Forest, Trees and People Newsletter, 43, 63-66.

Mallet, P., \& Karmann, M. (2000). Certification of non-timber forest products: An emerging field. www.fallsbrookcentre.ca.

May, P. H. (2004). Forest certification in Brazil. Paper presented at the Symposium forest certification in developing and transitioning societies: Social, economic, and ecological effects. Yale School of Forestry and Environmental Studies New Haven, CT, June 10 \& 11, 2004. Retrieved June 28, 2011, from http://yale.edu/forestcertification/symposium/pdfs/brazil_symposium.pdf.

MoEF. (1988). National forest policy 1988. Ministry of Environment and Forests, Government of India. http://moef.nic.in/divisions/fp/nfp.htm.

Muller, S., \& Durbeck, K. (2005). Guidance manual for organic collection of wild plants. Zürich, Switzerland: Swiss Import Promotion Programme (SIPPO). www.sippo.ch/files/publications/agri_ wildplants05.pdf.

Peluso, N. L. (1992). The rattan trade in East Kalimantan, Indonesia. Advances in Economic Botany, 9, $115-128$.

Perera, P., \& Vlosky, R. (2006). A history of forest certification. Retrieved April 9, 2009, from http://www.lfpdc.lsu.edu/unece/certificateEnvironment/documents/2003-2006/ce03_001.pdf. 
Pierce, A. R., \& Laird, S. A. (2003). In search of comprehensive standards for non-timber forest products in the botanicals trade. International Forestry Review, 5(2), 138-147.

Pierce, A. R., Shanley, P., Laired, S. A., et al. (2008). Non-timber forest products and certification: Strange bedfellows. Forests, Trees and Livelihoods, 18, 23-35.

Rametsteiner, E. (2000). Sustainable forest management certification. Frame conditions, system design and impact assessment. Vienna: Ministerial Conference on the Protection of Forests in the Europe, European Commission.

Rametsteiner, E., \& Simula, M. (2003). Forest certification-an instrument to promote sustainable forest management? Journal of Environmental Management, 67, 87-98.

Shanley, P., Pierce, A., Laird, S., et al. (2005). Beyond timber: Certification of non-timber forest products. A joint publication of Forest Trends, CIFOR and International People and Plants (pp. 1-68). Retrieved January 5, 2012, from http://www.cifor.org/online-library/browse/view-publication/publication/2543.html.

Shanley, P., \& Stockdale, M. (2008). Traditional knowledge, forest management, and certification: A reality check. Forests, Trees and Livelihoods, 18, 55-67.

Shanley, P., Pierce, A. R., Laird, S. A., Robinson, D. et al. (2008). Beyond timber: Certification and management of non-timber forest products. Bogor, Indonesia, Center for International Forestry Research (CIFOR). 144p. ISBN: 978-979-1412-44-5.

Sills, E., Shanley, P., Fiona, P., de Beer, J., Pierce, A., et al. (2011). Evolving perspectives on non-timber forest products. In S. Shackleton, C. Shackleton, \& P. Shanley (Eds.), Non-timber forest products in global context. New York: Springer.

SmartWood. (1999). Non timber forest product certification standards addendum. SmartWood, Practical Conservation through Certified Forestry, November, 1999. Retrieved March 1, 2011, from http://www.rainforest-alliance.org/forestry/documents/ntfp-addendum-generic-guidelines.pdf.

Stark, M., Min, D., Yongping, Y., et al. (2008). Eco-certification of non-timber forest products in China: Addressing income generation and biodiversity conservation needs. Ecological Economy, 4, $24-34$.

Turner, N. J., \& Loewen, D. C. (1998). The original 'free trade': Exchange of botanical products and associated plant knowledge in Northwestern North America. Anthropologica, 40, 49-70.

UNCED. (1992). United Nations Conference on Environment and Development (UNCED). Rio de Janeiro, 3-14 June, 1992. www.un.org/documents/ga/conf151/aconf15126-1annex1.htm.

UNCED. (2000). Report of the United Nations Conference on Environment and Development. United Nations Department of Economic and Social Affairs (DESA). United Nations. http://www.un. org/en/development/desa/climate-change/index.shtml.

Walter, S. (2002). Certification and benefit-sharing mechanisms in the field of non-timber forest productsan overview. Medicinal Plant Conservation, Volume 8, Newsletter of the IUCN Species Survival Commission, Medicinal Plant Specialist Group. Bonn. http://www.fao.org/DOCREP/ARTICLE/ 001/AB542E01.HTM.

Walter, S. (2006). Certification of non-timber wood forest products: Relevant standards, preliminary experiences and lessons-learnt. Paper presented at the 1st International Conference on Wild Organic Production Teslic, Bosnia Herzegovina, May 3-4, 2006. http://www.fao.org/docs/eims/upload/ 229898/OA-NWFP.pdf.

WCED. (1987). Our common future, report of the world commission on environment and development, World Commission on Environment and Development, 1987. Published as Annex to General Assembly document A/42/427, Development and International Co-operation: Environment August 2, 1987. www.un-documents.net/wced-ocf.htm.

Weinstein, B. (1983). The Amazon rubber boom. Stanford, CA: Stanford University Press.

WHO. (2003). World Health Organization (WHO) Guidelines on Good Agricultural and Collection Practices (GACP) for Medicinal Plants. Geneva, Switzerland. http://whqlibdoc.who.int/publications/ 2003/9241546271.pdf.

Wiersum, K. F., Gole, T. W., Gatzweiler, F., Volkmann, J., Bognetteau, E., Wirtu, O., et al. (2008). Certification of wild coffee in Ethiopia: Experiences and challenges. Forests, Trees and Livelihoods, 18(1), 9-21.

Wolters, O. W. (1967). Early Indonesian commerce: A study of the origins of Srivijaya. New York, NY: Cornell University Press.

WSSD. (2002). World summit on Sustainable Development (WSSD) Johannesburg, August 26-September 4, 2002. http://www.worldsummit2002.org.

Yadav, M., Kotwal, P. C., Patnaik, S., James, K., et al. (2003). Proceedings of the sensitisation workshop on forest certification organised by IIFM during July 2-3, 2003, at Bamboo and Cane Development Institute, Agartala. Bhopal: IIFM. ISBN: 81-7969-012-1.

Yadav, M. (2012). Forest certification: A marketing tool for sustainable forest management. IIFM under finalization for publication. (Unpublished). 
Yadav, M., \& Dugaya, D. (2009). Timber forest certification scenario: an overview. Paper presented in the International Workshop on "Production and Marketing of Teakwood: Future Scenarios" organized by the TEAKNET in collaboration with the Kerala Forest Research Institute during 23-25 November, 2009 at KFRI, Peechi, Kerala, India. http://www.teaknet.org/publications.

Yadav, M., Kotwal, P. C., Menaria, B. L., et al. (2007). Forest Certification-a tool for sustainable forest management. Bhopal: Indian Institute of Forest Management. ISBN: 81-7969-047-4. http://www. iifm.ac.in/sfmfc/Monograph\%20on\%20Forest\%20certification.pdf.

Yadav, M., \& Misra, S. (2010). Role of role of non-timber forest products based enterprises in sustaining incomes of forest dwellers. In A. Ghosh, Karthik, \& S. Sharma (Eds.), Proceedings (papers) of the international conference on challenges to inclusive growth to emerging economies (pp. 77-81), Ahmadabad: Indian Institute of Management.

Yadav, M., Dugaya, D., Basera, K. et al. (2011). Opportunities and Challenges for NWFP certification in India. Paper presented at International Conference on Non Wood Forest Produce for sustained livelihood during December 17-19, 2011 at Bhopal, India.

\section{Websites visited and referred in the article include}

http://www.fsc.org/facts-figures.html. Accessed April 23, 2012 and August 14, 2012.

http://www.itto.int/annual_review_output/?mode=searchdata. Accessed September 13-14, 2011.

www.mtcc.com.my. Accessed April 23, 2012.

www.treefarmsystem.org. Accessed August 30, 2011.

http://www.csa.ca/cm/ca/en/home. Accessed August 30, 2011.

http://www.sfiprogram.org/sustainable_forestry_initiative_standard.php. Accessed August 30, 2011.

http://pulp-paperworld.com/asian-news/item/1318-pefc. Accessed September 9, 2011.

http://www.envfor.nic.in/fsi/sfr99/chap3/up/uttar.html. Accessed September 9, 2011.

www.fao.org. Accessed April 23, 2012.

http://www.itto.int. Accessed September 20, 2011.

www.pefc.org. Accessed April 23, 2012, August 14, 2012 and September 8, 2012.

http://www.iifm.ac.in/ntfp/index.htmlm. Accessed April 23, 2012. 